\title{
Sources of Bureaucratic Delay: A Case Study of FERC Dam Relicensing
}

\author{
Lea-Rachel D. Kosnik \\ University of Missouri-St. Louis
}

\begin{abstract}
This paper investigates the sources for regulatory delay in bureaucratic decision making, testing regulatory capture, congressional dominance, and bureaucratic discretion theories of agency behavior. The empirical context concerns relicenses issued by the Federal Energy Regulatory Commission (FERC) for hydroelectric dams, which have taken anywhere from just ten months to over sixteen years to be issued. The reasons for this heterogeneity in regulatory processing times can be expected to be varied and numerous and indeed we find evidence that outside interest groups, the legislature, and bureaucratic discretion are all significant in affecting regulatory processing times. Our most intriguing results concern the effects of environmental interest groups, which, despite their apparent benefit/cost motivation to hasten the relicensing process (independent of relicensing outcomes), overall end up slowing it down.
\end{abstract}

\section{Introduction}

Bureaucratic delay appears to be an increasingly prevalent characteristic of regulatory agency decision making. In 1992, the Food and Drug Administration (FDA) instituted user fees to try to quicken lengthy drug approval times. In 1997, in his State of the Union Address, Bill Clinton touted increased Superfund cleanup speed as a priority for the Environmental Protection Agency. Currently, the national energy bill being debated in the U.S. Congress includes an amendment (Title III) aimed at reform of the hydroelectric dam relicensing process, including an attempt to speed up the time it takes for a relicense to be issued by the Federal Energy Regulatory Commission (FERC). If, as it appears to be, an increasingly prevalent policy goal of the federal government is to reform the speed of bureaucratic decision making, a natural question to ask is: What determines bureaucratic delay? This paper, which utilizes a unique and extensive data set of many of the variables hypothesized to affect the hydroelectric dam relicensing process in particular, is an attempt to formulate an answer. By seeking an understanding of the determinants of delay in this specific context, this paper hopes to shed light on the broader sources of bureaucratic delay in general.

Most empirical analyses of regulatory agency decision making in the literature focus on regulatory outcomes, not decision-making times. Which types of drugs are favored for approval by the FDA (Olson, 1995)? Which species are more likely to get listed under the Endangered Species Act (ESA) (Ando,

The Journal of Law, Economics, \& Organization, Vol. 22, No. 1, doi:10.1093/jleo/ewj004

Advance Access publication October 26, 2005

(c) The Author 2005. Published by Oxford University Press. All rights reserved. For Permissions, please email: journals.permissions@oxfordjournals.org 
2001)? What licensing requirements does FERC usually implement (DeShazo and Kosnik, 2003) ${ }^{1}$ This lack of comparable literary attention to the length of time it takes to reach a regulatory outcome is puzzling, as timing can be as significant a policy variable as final regulatory outcomes. ${ }^{2}$ In the context of hydroelectric dam relicensing, timing has indeed become an increasingly variable factor of the process. A quick look at the hydroelectric licenses issued by FERC between 1982 and 1998 shows that $27 \%$ of all licenses took longer to issue than the scheduled five years, ${ }^{3}$ with the longest license taking over 21 years to complete (Table 1). ${ }^{4}$ This trend has grown in recent years, with later applications languishing longer. ${ }^{5}$

Ultimately, a public choice view of bureaucratic behavior would assume that net delay (or haste) is the result of benefit/cost considerations of the players involved in the regulatory process. In the context of hydroelectric dam relicensing, costs associated with delayed licensing decisions include annual administrative fees (for the licensee alone this has been estimated at around \$1 million a year), investment uncertainty for the dam owner until a new license is secure, and continued environmental degradation until a new license, often with stricter environmental operating conditions, is issued. The primary benefit of a delayed relicense is the postponement of implementation of any new costly licensing requirements. While rarely quantified, these requirements (which are primarily environmental mitigation requirements) include things such as fish ladders, water quality improvements, aesthetic improvements, and preservation of historic sites, which can easily double the operating costs of the dam. Box Canyon Dam in Bonner County, Idaho, for example, enmeshed in the relicensing process since 1995, has been required to install a fish ladder, bike paths, nature trails, and other environmental amenities, which together are estimated to cost around $\$ 500$ million. Until a license is officially issued, however, these costs can be postponed. Delay may also benefit particular interest groups involved in the relicensing process by adding the time necessary to increase the legitimacy and accuracy of any final proposed regulatory requirements.

1. This paper will take the reverse approach, focusing on regulatory processing times (as the dependent variable) and not final regulatory outcomes. Such an approach assumes a degree of (perhaps unrealistic) independence between the timing and outcome variables, but, while not fully realistic, such an assumption has not prevented useful conclusions to be drawn from previous papers (such as those mentioned above) modeling regulatory outcomes alone, and we believe the same holds true with this model of regulatory processing times.

2. Lawyers, if not economists, have long recognized the significance of delay as a policy option. Legal cases involving Microsoft, IBM, and capital punishment sentencing have all effectively utilized delay as a practical strategic outcome.

3. The hydroelectric relicensing handbook (FERC, 1990) states that relicense applications should take only five years to complete.

4. And this is likely an underestimate, as the licenses not officially completed at all in that time frame were not included in the data set.

5. Simple regression analysis of licensing time on relicensing date, after having first divided the sample into two subsets (1982-1990 and 1991-1998) finds that the relicensing date coefficient in the second sample is positive and significant, while in the first sample it is actually negative, although not significant. 
Table 1. Time- to- Relicense Tabulation

\begin{tabular}{lcc}
\hline Time to Relicense & \% obs. & \% cum. \\
\hline Less than 1 year & 8.11 & 8.11 \\
$1<t<2$ & 14.86 & 22.97 \\
$2<t<3$ & 26.58 & 49.55 \\
$3<t<4$ & 10.36 & 59.91 \\
$4<t<5$ & 13.06 & 72.97 \\
$5<t<6$ & 14.42 & 87.39 \\
$6<t<7$ & 3.6 & 90.99 \\
$7<t<8$ & 1.35 & 92.34 \\
$8<t<9$ & 0.45 & 92.79 \\
$9<t<10$ & 1.35 & 94.14 \\
$10<t<11$ & 0 & 94.14 \\
$11<t<12$ & 1.36 & 95.5 \\
$12<t<13$ & 0.45 & 95.95 \\
$13<t<14$ & 0.45 & 96.4 \\
$14<t<15$ & 1.35 & 97.75 \\
$15<t<16$ & 0.9 & 98.65 \\
$16<t<17$ & 0 & 98.65 \\
$17<t<18$ & 0.45 & 99.1 \\
$18<t<19$ & 0.45 & 99.55 \\
$19<t<20$ & 0 & 99.55 \\
$20<t<21$ & 0 & 99.55 \\
$21<t<22$ & 0.45 & 100 \\
\hline
\end{tabular}

Building on the assumption that regulatory delay (as with final regulatory outcomes) occurs as the result of a balancing of costs and benefits, we develop three testable hypotheses for the source of bureaucratic delay. First, stemming from the regulatory capture literature, we hypothesize that outside interest groups are significant factors in affecting relicensing process times. We would expect to find that dam owners and power intervenors mostly seek to slow down the relicensing process in order to postpone financially constraining environmental mitigation requirements. Meanwhile, we expect that environmental interest groups would in general seek to hasten a relicensing process (independent of final relicensing outcomes) in order to save endangered resources associated with a river before they go extinct. What our empirical results show is that both groups of intervenors are significantly effective at slowing down the relicensing process. This intriguing result is explored in detail with regressions that break down the environmental "coalition" into specific advocacy cohorts in order to investigate the individualized delaying or hastening effects each advocacy type has on the bureaucratic process; it appears that certain environmental interest groups may benefit more from the increased legitimacy and accuracy of final regulatory requirements (which are strengthened by delay) than they would from any increased speed and hastened environmental end benefits from the regulatory process itself.

Our second testable hypothesis, based on theories of congressional dominance, is that Congress may affect the timing of bureaucratic processes. 
If a relatively liberal and environmentally friendly Congress (as measured by a state senator's combined League of Conservation Voters' score) is in session when a project is up for relicensing before FERC, we would expect to find that the speed of FERC's relicensing decision is significantly hastened, again in order to save endangered resources associated with a river before they go extinct. ${ }^{6}$ We would also expect to find that passage of the Electric Consumers Protection Act (ECPA) in 1986, whose purpose was to push FERC toward greater consideration of environmental interests, would similarly lead to a hastening of the regulatory process. ${ }^{7}$ Indeed, our legislative variables have these effects. The coefficients on these two variables are the largest in our analysis, which suggests that the legislature can have a real effect on bureaucratic decision making.

Our final hypothesis is that the regulatory agency itself, FERC, maintains a degree of bureaucratic discretion. Workload burden, for example, may be a significant source of delay in the relicensing process. Our results show that while the number of other projects that a regional FERC office has to process when a new hydroelectric project comes up for relicensing is actually insignificant in affecting processing times, other workload variables such as size of a project, gross storage capacity, and value of electricity production are all significant in delaying relicensing times. Larger projects, particularly those that produce more valuable electricity, seem to take longer to be relicensed.

This paper contributes to the burgeoning literature on bureaucratic decision making in two ways. First, it tests three current hypotheses of bureaucratic behavior: (1) that interest groups can affect the regulatory process (regulatory capture theory), (2) that the legislature can affect bureaucratic behavior (congressional dominance theory), and (3) that case-specific effects influence bureaucratic behavior (regulatory discretion theory), and it tests these theories in particular as they influence regulatory delay, as distinct from the larger literature on final regulatory outcomes. Second, this paper presents a unique empirical analysis of FERC and the hydroelectric relicensing process. ${ }^{8}$

6. Because our empirical results show that environmental interest groups do not homogeneously favor haste, there is uncertainty in predicting which direction a relatively environmentally friendly Congress would influence licensing times. We believe, however, that a more liberal legislature would seek to affect regulatory haste (and not delay), because of all the environmental benefits considered in any relicensing decision, the one with the greatest saliency and constituency awareness (Yaffee, 1982) is endangered resources. These environmental benefits in particular definitively gain from increased regulatory speed.

7. Further support for the argument that more liberal legislative action would seek to affect regulatory haste (and not delay) comes from the wording of the ECPA itself. While the ECPA was intended to benefit all "aspects of environmental quality," the only environmental benefit mentioned with any degree of specificity in the textual language of the document is the "enhancement of fish and wildlife (including related spawning grounds and habitat)"-in other words, endangered resources, which again benefit most from regulatory speed.

8. A more limited empirical study by Moore et al. (2001) investigates FERC's decision to implement just the fish and wildlife mitigation requirements for a select number of hydroelectric licenses between 1980 and 1996. DeShazo and Kosnik (2003) also investigate aspects of FERC decision making, but their focus too is on final regulatory outcomes. No previous study that the author is aware of has investigated the topic of regulatory delay in the hydroelectric relicensing process, particularly with a data set as extensive as the one utilized in this paper. 
The rest of this paper proceeds as follows: Section 2 explores the background of FERC and the hydroelectric dam relicensing process, Section 3 presents a theoretical framework for analyzing delay in bureaucratic decision making, Section 4 goes over the data, Section 5 discusses the empirical approach, Section 6 summarizes the results, and Section 7 offers concluding implications.

\section{Background}

\subsection{FERC and the Federal Power Act}

In the late $1800 \mathrm{~s}$, when the Industrial Revolution was at its height and economic development of the nation was at center stage, the federal government officially began monitoring development of the nation's riverine resources. Energy generation was at the core of the nation's burgeoning prosperity, and hydropower production was just one important and growing subset of that core industry. In the late 1800 s permits for hydroelectric production were being issued by the secretary of war, but by 1920 hydropower generation had reached 20 billion kilowatt-hours of electric power per year, from an operating capacity of 4800 megawatts, and the nation's appetite for hydroelectric production was still far from satiated. There was a clear need for the creation of a more coordinated and centralized federal regulatory authority focused specifically on hydropower development issues.

In 1920 Congress passed the Federal Water Power Act (FWPA) to streamline the administrative processes involved in hydropower regulation, and more importantly, to create a single regulatory agency focused entirely on developing and encouraging hydropower production in the United States. That agency, whose clearly stated objective included a strong focus on encouraging hydropower production, was the Federal Power Commission.

The FWPA was replaced by the Federal Power Act (FPA) in 1935, and with the transformation, the Federal Power Commission was expanded within the Department of Energy to become FERC. But although the names changed and the regulatory jurisdictions were altered slightly, the primary objective of the commission has remained, for over 50 years, the development and encouragement of hydropower production in the United States.

Competing demands for the services of the nation's rivers toward ends other than hydropower development (e.g., recreational, fish and wildlife, archaeological objectives) did not begin to make true inroads into official legislative expression until the late 1960s and early 1970s. At that time a slate of legislation passed reflecting society's increasing preferences for protection and enhancement of environmental resources. ${ }^{9}$ These acts forced FERC to formally open up the regulatory process and involve commentary from outside resource agencies and interest groups. This interaction between FERC and outside agencies in the regulation of the hydroelectric industry is an aspect of the regulatory process that has been further strengthened in subsequent legislation.

9. Prominent among this new legislation was the National Environmental Policy Act (NEPA) of 1969, the National Historic Preservation Act (NHPA) of 1966, the Wild and Scenic Rivers Act (WSRA) of 1968, and the Endangered Species Act (ESA) of 1973. 
While none of this initial legislation was directly aimed at the FPA, much of it did indeed indirectly alter FERC's administrative process by forcing FERC to consider new environmental details, objectives, and filings when regulating hydropower applications and relicenses. ${ }^{10}$ It also strengthened the role of outside resource agencies in the relicensing process and asserted society's desire to balance the environmental impacts of hydropower projects against their power benefits. FERC's official statutorial objective may have remained the development of hydropower production in the United States, but now this objective was balanced against an environmental awareness of the implications of hydropower production.

This increasing competition between power and nonpower objectives for the use of the nation's river resources continued throughout the 1970s and 1980s. Minor pieces of legislation that supported the hydropower objectives in the debate passed as well, such as the Energy Tax Act, the Energy Security Act, and the Economic Recovery Act. In 1986 the first piece of legislation since 1935 to directly amend the FPA was passed. The ECPA not only established an official role for resource management agency recommendations in the (re)licensing process, but modified FERC's regulatory objective so that "in addition to the power and development purposes for which licenses are issued, [FERC] shall give equal consideration to the purposes of enhancement of fish and wildlife (including related spawning grounds and habitat), the protection of recreational opportunities, and the preservation of other aspects of environmental quality" (FERC, 1990:136).

FERC itself now has the mandate to balance the power and nonpower interests involved in the allocation of the nation's riverine resources toward its competing end uses. Over the past fifteen years, FERC has been struggling to interpret this new mandate and to decide just how, in practice, to balance these competing interests. Increasingly, it appears that time-to-license, and not just ultimate license requirements, has been used as a variable in this decisionmaking process. As the history of FERC's creation and development shows, interest group pressure, legislative action, and bureaucratic discretion have all had their part to play in shaping FERC's regulatory behavior.

\subsection{The Relicensing Process}

In the United States today, there are over 70,000 working dams. Most of these are small structures with a crest elevation of less than 50 feet or a hydroelectric generation capacity of less than 5 megawatts. Of the larger dams that remain, some are federally owned (the most familiar being Hoover Dam, Grand Coulee Dam, and Shasta Dam) and the rest are nonfederal, or privately owned. ${ }^{11}$ These

10. See McCubbins et al. (1987) for further exposition on legislative administrative procedures as instruments of political control.

11. While nonfederal dams are commonly labeled "private," this is somewhat misleading, as many nonfederal dams are in fact owned by local or state governmental entities. For example, Azusa Dam on the San Gabriel River in California is owned by the City of Pasadena. The key is that they are nonfederal and so come under the jurisdiction of FERC. 


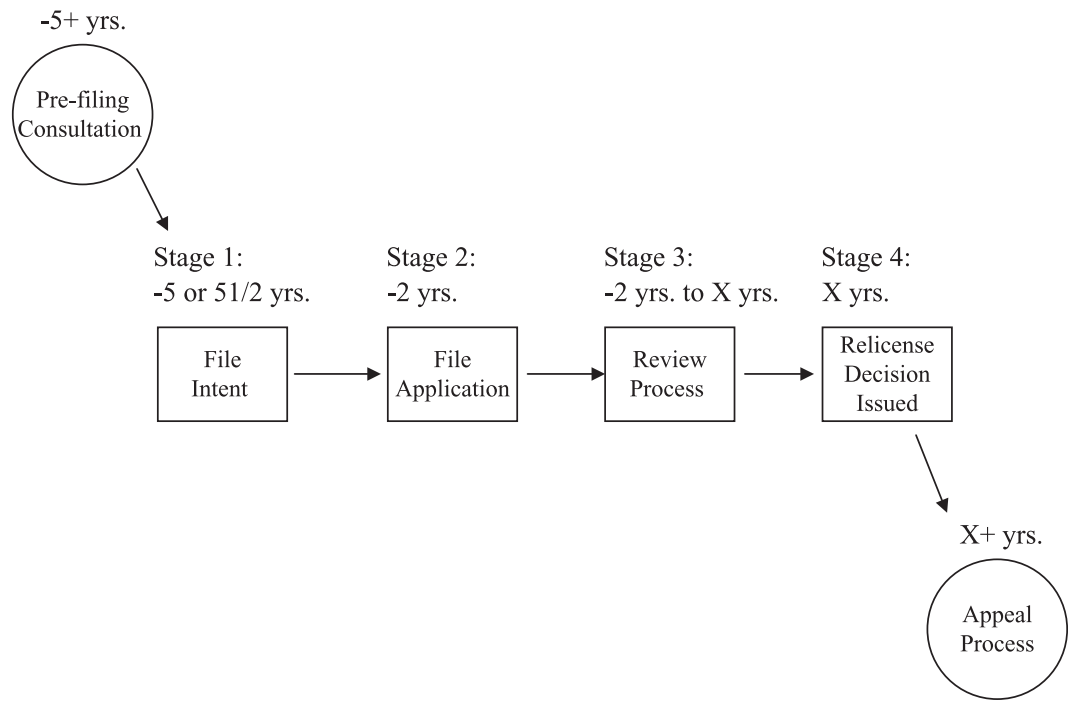

Diagram 1. The Relicensing Process.

nonfederal dams all come under the regulating authority of FERC, which since 1935 has issued thousands of licenses, for terms of 50 years or less. At the end of an initial license period, the dam owner must file for a relicense, again not to exceed 50 years, in order to legally continue operation.

The official relicensing process takes place in four rough stages (Diagram 1) and is expected to average five years to completion. The first formal deadline, which must occur at least five, but not more than five and a half, years before the expiration of a current license, is when the licensee files a Notice of Intent stating that it intends to file an application for a new license, and submits to FERC a lot of technical information regarding the project. ${ }^{12}$ After submission, the licensee then begins to prepare the relicensing package, which includes consultations with state and federal resource agencies and certification of water quality under the Clean Water Act.

At least 24 months before the existing license expires, the licensee must then file an actual relicense application. FERC reviews the application, seeks

12. Pre-filing consultations (before stage 1 begins) may take place between the licensee, FERC, and public resource agencies, in order to get a feel for the necessary studies and information that a license package will require, before the formal filing of a notice of intent. Such discussions, however, are unofficial and not recorded on the project's docket sheet, a primary source of data on the hydroelectric relicensing process. By necessity, therefore, this study does not include any pre-filing consultations as part of the relicensing timeline. As these consultations are in any event at the behest of the licensee, not FERC, they are not a part of the regulatory delay we are seeking to explain, though admittedly, better pre-preparation might induce quicker relicensing times once the formal process is under way. Any such effect, if it exists, may show up in the owner characteristic variables included in the empirical analysis and described in the next section. 
additional information or studies, and, upon approval, eventually formalizes it with a notice in the Federal Register. It is most commonly at this point (stage 3) in the relicensing process that a wide range of interest groups (see Table 2) actively submit comments, protests, and requests for information or further studies from FERC or the licensee. The relicensing process is the only official opportunity during the lifetime of a dam for a complete review of its safety and operations. It is also the only opportunity for interest groups and concerned individuals to influence the operations of the dam through the formal regulatory process. It is clear that most of the variability in processing time is associated with this stage.

The final step occurs when FERC holds a hearing regarding the relicense application and issues its regulatory decision. It has three options: (1) relicense the project, thereby authorizing its continued hydropower generation and operation, (2) recommend a federal takeover of the project (with compensation given to the current owner) and have it operated by the government, or (3) issue a nonpower license (to either a public or a private entity), to facilitate conversion of the project to a nonhydropower use. The project's reservoir could be managed exclusively for recreational use, for example; or the dam could be removed entirely and the river restored to a free-flowing condition. In practice, rarely has FERC issued anything other than a relicense, albeit relicenses increasingly carry mitigating safety and environmental requirements that make them not just stamps on the status quo. In FERC's nearly 70 year history of managing hydropower projects, only once has it not issued a new relicense. $^{13}$

An additional stage in the relicensing process can take place if one of the official intervenors to the relicensing process chooses to appeal FERC's relicensing decision; in such an instance a review of the decision is conducted by the five FERC head commissioners. Barring finality of that decision, the last word is reserved for the U.S. Court of Appeals.

Trends in the last couple of decades have shown that this relicensing process is taking longer and longer to complete. Two of the initial three hypotheses concerning the determinants of this delay - interest group effects and workload effects - originate from stage 3 of the relicensing process, where interest group comments and requests for information are correlated with increased processing times. What all parties to the relicensing process ultimately hope to affect is the number and type of environmental requirements that the regulatory agency, FERC, issues as a condition for a relicense; but in the process, relicensing time itself has become an increasingly variable factor. In the following section, we present a simple model that formalizes FERC's decisionmaking behavior in issuing a new relicense, with a given set of mitigating requirements and in a certain amount of time.

13. In 1997 FERC ordered that Edwards Dam, on the Kennebec River near Augusta, Maine, be removed through federal takeover. Funding for the dam removal and fish restoration efforts was in part provided from private and nongovernmental organizations. 
Table 2. Intervenor Descriptions and Examples

\begin{tabular}{|c|c|c|c|c|c|c|}
\hline Power & Sportfishing & Boating & Historic/Archaeology & Endangered Species & Water Supply & Recreation \\
\hline $\begin{array}{l}\text { WI River } \\
\text { Power Co. }\end{array}$ & California Trout & $\begin{array}{l}\text { Georgia Canoeing } \\
\text { Assn. }\end{array}$ & $\begin{array}{l}\text { Alabama Historical } \\
\text { Commission }\end{array}$ & WA Dept. of Wildlife & $\begin{array}{l}\text { ID Dept. of Water } \\
\text { Resources }\end{array}$ & $\begin{array}{l}\text { Adirondack } \\
\quad \text { Mountain Club }\end{array}$ \\
\hline $\begin{array}{l}\text { WI Public } \\
\text { Service Dept. }\end{array}$ & $\begin{array}{l}\text { Pacific Fishery } \\
\text { Mgt. Council }\end{array}$ & $\begin{array}{l}\text { CA Boating \& } \\
\text { Waterways }\end{array}$ & $\begin{array}{l}\text { Fernbank Museum of } \\
\text { Natural History }\end{array}$ & VA Game Department & $\begin{array}{l}\text { CO Div. of Water } \\
\text { Resources }\end{array}$ & $\begin{array}{l}\text { NY Parks \& } \\
\quad \text { Recreation }\end{array}$ \\
\hline $\begin{array}{l}\text { Niagara Mohawk } \\
\text { Power }\end{array}$ & $\begin{array}{l}\text { Bumble Bee } \\
\text { Seafoods }\end{array}$ & $\begin{array}{l}\text { Southeastern } \\
\text { Expeditions }\end{array}$ & $\begin{array}{l}\text { CA Office of Historic } \\
\text { Preservation }\end{array}$ & $\begin{array}{l}\text { Chippewa \& Flambeau } \\
\text { Improvement Co. }\end{array}$ & $\begin{array}{l}\text { Diamond Fruit } \\
\text { Growers }\end{array}$ & $\begin{array}{l}\text { Little River Camping } \\
\quad \text { Resort }\end{array}$ \\
\hline $\begin{array}{l}\text { UT Muni. } \\
\text { Power Agency }\end{array}$ & $\begin{array}{l}\text { Federation of } \\
\text { Fly Fishers }\end{array}$ & $\begin{array}{l}\text { Six Rivers } \\
\quad \text { Paddling Club }\end{array}$ & CO Historical Society & UT Wilderness Association & $\begin{array}{l}\text { Deerskin } \\
\text { Lake Assn. }\end{array}$ & $\begin{array}{l}\text { NH Timberland } \\
\text { Owners Assn. }\end{array}$ \\
\hline
\end{tabular}




\section{Theoretical Framework}

When a new hydroelectric project is filed before FERC for a relicensing decision, immediately the commission begins to feel pressure regarding its forthcoming relicensing decision. It faces pressure on the substantive outcome of the relicensing decision, $o_{i}$ (the environmental mitigation requirements, for project $i$ ) and it faces pressure on the speed of its decision, $t_{i}$ (through interest group complaints, internal pressure, and legislative sticks such as Title III reform). Any particular FERC relicensing decision, $D_{i}$, is therefore a composite of outcome and timing considerations: $D_{i}\left(t_{i}, o_{i}\right)$.

In choosing these outcome and timing variables, FERC must balance pressure from political actors (congress) and outside (environmental and hydroelectric) interest groups. Its main goal is pressure minimization because, as noted in Joskow (1974), Noll (1974), and Magat et al. (1986), adverse pressure from congressional and outside interest groups can lead to budget reductions, oversight, distracting investigations, and negative public relations. Previous research has detailed the link between Congress and interest group pressure on regulatory outcomes, $o_{i}$ (DeShazo and Kosnik, 2003). This paper seeks to test some of these same effects on timing, $t_{i}{ }^{14}$

The model assumes that FERC has exogenously determined resources to move projects through the relicensing process. ${ }^{15}$ Let $b$ represent FERC's total available resource budget and $r_{i}$ represent resources devoted to site $i$. The length of time through the relicensing process, $t_{i}$, decreases as more resources, $r_{i}$, are devoted to a particular project. A project's technical complexity and workload burden, however, may also affect speed, implying that resources affect speed through an agency production function, $a\left(r_{i}, S_{i}\right)$, where $S_{i}$ represents project characteristics.

To summarize the pressure forces acting on FERC, we assume that there are costs and benefits to the agency that result from any relicensing decision, $D_{i}$. These net costs, $c_{i}$, depend on the length of time spent in the relicensing process and on pressures from affected parties as represented by $I_{i}\left(t_{i}, o_{i}\right)$ (outside interest groups) and $P_{i}\left(t_{i}, o_{i}\right)$ (legislative oversight), such that $c_{i}=c_{i}\left(t_{i}, I_{i}, P_{i}\right)$.

A general null hypothesis is that FERC seeks to minimize pressure costs across all projects, subject to its resource constraint and agency production function:

$$
\min _{r_{i}} \sum_{i=1}^{N} c_{i}\left(t_{i}, I_{i}, P_{i}\right)
$$

$$
\text { subject to } t_{i} \geq a\left(r_{i}, S_{i}\right), \quad \sum_{i=1}^{N} r_{i} \leq b \text { and } r_{i} \geq 0,
$$

where $N$ is the total number of projects to be relicensed.

14. We do this while abstracting, at least in the theoretical model, from any interaction between the outcome and timing variables.

15. This model is loosely based on the one found in Sigman (2001). 
The input $r_{i}$ is not directly observable and is less relevant for policy prescriptions than are the output variables $t_{i}$ and $o_{i}$. This analysis focuses on the reduced-form relationships between $t_{i}$, in particular, and the variables above:

$t_{i}=A\left(I_{i}, P_{i}, S_{i}, b\right)$

Our model gives us three testable hypotheses.

\section{Hypothesis 1}

H1: Interest group pressure $\left(I_{i}\right)$ is significant in affecting relicensing processing times; in particular, hydropower pressure groups increase relicensing processing times (delay), while environmental pressure groups decrease relicensing processing times (haste).

Previous research investigating regulatory processing times of other federal agencies finds evidence to support our first hypothesis, that outside interest groups are significant factors affecting bureaucratic behavior. In an early study of the Environmental Protection Agency's (EPA) implementation of the ESA, Yaffee (1982:132) notes, "The most consistently effective pressure was that from outside support groups." Delay appears to be the most common outcome of interest group effort, but Yaffee notes that interest groups can also work to hasten a regulatory process if it is in their interests to do so. In a more recent study of the timing decisions of the EPA with regard to the ESA, Ando (1999) similarly finds evidence that interest group pressure can slow, or indeed hasten, the progress of candidate species through the listing process. In an examination of the length of time that sites spend on Superfund's National Priorities List (NPL), Sigman (2001) finds empirical evidence that the EPA, in this instance as well, is influenced by outside interest groups. Finally, Carpenter (2002) has found that outside interest groups are important in affecting bureaucratic delay at the Food and Drug Administration (FDA).

In the context of hydroelectric dam relicensing, we would predict that hydroelectric and power interest groups would seek to delay the relicensing process in order to preserve current generating capacity and avoid costly environmental mitigating requirements, while environmental interest groups, which have a strong interest in seeing the relicensing process completed and all environmental requirements finally implemented, would in the aggregate (and independently of outcome decisions) seek to hasten relicensing processing times.

\section{Hypothesis 2}

H2: Legislative pressure $\left(P_{i}\right)$ is significant in hastening relicensing processing times 
The theoretical foundation for the hypothesis that interest group pressure can affect agency decision making stems, of course, from the seminal works by Stigler (1971), Peltzman (1976), and Becker (1983) on regulatory capture theory and interest group effects, but alternative theories have also been put forward suggest that other variables might also influence the regulatory process. Weingast and Moran (1983), McCubbins et al. (1987), Gilligan et al. (1989), and Helland (1999) all present evidence for legislative effects on agency decision making, and as Olson (1995) has found that no single theory appears to explain the entirety of agency decision making, this analysis also includes variables proxying for the potential effect of legislative pressure on FERC decision making. Empirical evidence to support inclusion of legislative variables when attempting to explain regulatory delay in particular comes from Hird (1990), who discovered that legislators can hasten a Superfund site's transition by the EPA from proposed to final NPL status. We would expect that the more environmentally friendly the disposition of Congress, the more quickly relicensing projects are completed. Individual legislators, in accordance with Mayhew (1974), may be captured by the more concentrated hydropower interests and seek delay in relicensing times, but given initial legislator proclivities, the more liberal the congressional body when a particular project comes up for relicensing, the greater the pressure will be toward affecting regulatory haste.

\section{Hypothesis 3}

\section{H3: Workload burden $\left(S_{i}, b\right)$ is significant in delaying relicensing processing times}

In determining the source of delay in the hydroelectric relicensing process, a reasonable final hypothesis is that delay is simply the result of increased workload. A majority of the 1009 private hydroelectric projects that FERC is responsible for relicensing were built just after World War II and received initial 40- to 50-year licenses. ${ }^{16}$ As such there is an overflow of projects needing to be relicensed by FERC. In 1983, for example, only two projects were relicensed by the commission, while that number jumped to 24 in 1993 and 44 in 1994. Between 1998 and 2010, nearly one thousand dams, affecting over one hundred different rivers, will need to be reviewed and relicensed (note that a "project" may include more than one dam). FERC itself has at times claimed high volume of workload and limited budgets as sources of its bureaucratic delay. A complete empirical analysis should control for possible workload effects on processing times at FERC regional offices across the country.

16. FERC is in fact responsible for 1600 private hydroelectric projects, but 591 of these have received permanent exemptions from the licensing process, due primarily to minimal generating capacity. 
While workload varies as the total number of projects to process varies, workload itself may be affected by other factors as well. If the gross number of projects stays the same, but their size and complexity or the contentiousness of their regulation increases, these case-specific factors can also constitute increases in workload, leading to increases in regulatory processing times. In empirical analyses of drug approval times by the FDA, for example, Dranove and Meltzer (1994) and Olson $(1997,2000)$ both found that the speed of drugs through the regulatory process is significantly affected by the "importance" of the drug. Other studies, not on regulatory processing times but on final regulatory outcomes, by Magat et al. (1986), Bartel and Thomas (1987), Cropper et al. (1992), Olson (1995, 1997, 2000), Mixon (1994), Crone and Tschirhart (1998), and Ando (2001), confirm that case-specific variables are generally significant in affecting regulatory decisions. This analysis includes a host of case-specific variables, including size of the dam being relicensed, environmental quality of the river upon which the dam is being relicensed, and value of the electricity generated by the dam in order to determine these alternative workload factors which of may affect regulatory delay.

\section{Data}

The data for this study were culled from three sources: the license and docket sheets for 222 hydroelectric projects all relicensed by FERC between 1982 and 1998, an internal FERC database that contains a host of descriptive characteristics on each of the above projects, and public and governmental records on political and river-basin characteristics pertaining to the projects under study. Summary statistics are given in Table 3.

The dependent variable is a measure of the time to relicense of a hydroelectric dam relicensing application. It is measured in days and begins on the official filing date of a relicense application (at the beginning of stage 1 on Diagram 1), and concludes with the formal issuance of a project relicense (at the end of stage 4 on Diagram 1). As our observation set does not include projects that were begun but not completed by 1998, a degree of censoring occurs. It is worth keeping in mind, therefore, the slight downward bias on the estimates presented later in the empirical section. ${ }^{17}$

Figure 1 gives the Kaplan-Meier estimate of the survival curve for the timeto-license variable in our study. Notice the steady downward survival probability from 0 to 2000 days. At 2000 days (approximately 5 $\frac{1}{2}$ years), a kink occurs in the survival estimate curve, signifying that if a project hasn't come to a successful completion by that time, it may end up languishing in the regulatory process for as much as 10 additional years. Table 1 shows that the percentage of relicense applications to take longer than 5 years is $27 \%$, a significant percentage that is the likely impetus for the policy reform now being debated in Congress.

17. Unfortunately, the data to formally correct for the possibility of a downward bias due to censoring were unavailable. 


\begin{tabular}{|c|c|c|c|c|}
\hline \multirow[b]{2}{*}{ Variable } & \multicolumn{2}{|c|}{$N=222$} & \multirow[b]{2}{*}{ Min. } & \multirow[b]{2}{*}{ Max. } \\
\hline & Mean & SD & & \\
\hline \multicolumn{5}{|l|}{ Dependent Variable } \\
\hline Time to relicense & 1473.104 & 1204.315 & 87 & 7674 \\
\hline \multicolumn{5}{|l|}{ Workload Vars. } \\
\hline Other projects & 33.788 & 26.719 & 1 & 77 \\
\hline New York office & 0.347 & 0.477 & 0 & 1 \\
\hline Atlanta office & 0.122 & 0.328 & 0 & 1 \\
\hline Portland, OR, office & 0.077 & 0.267 & 0 & 1 \\
\hline San Francisco office & 0.099 & 0.299 & 0 & 1 \\
\hline Dam height & 50.171 & 66.156 & 0 & 661 \\
\hline $\mathrm{kW} / 10^{3}$ & 21.629 & 66.519 & 0 & 650.25 \\
\hline Gross storage $/ 10^{3}$ & 92.162 & 418.596 & 0 & 4959 \\
\hline Drainage area/ $10^{3}$ & 3.404 & 8.644 & 0 & 89.4 \\
\hline Dam year & 24.698 & 22.325 & 0 & 99 \\
\hline Endangered river & 0.18 & 0.385 & 0 & 1 \\
\hline Endangered species & 3.748 & 4.416 & 0 & 33 \\
\hline Run-of-river & 0.64 & 0.481 & 0 & 1 \\
\hline Electricity price & 7.833 & 1.832 & 3.559 & 13.433 \\
\hline Private owner & 0.64 & 0.481 & 0 & 1 \\
\hline Multiple owner & 0.77 & 0.422 & 0 & 1 \\
\hline Total requirements & 10.477 & 5.715 & 0 & 28 \\
\hline \multicolumn{5}{|l|}{ Political Vars. } \\
\hline LCV score & 0.628 & 0.242 & 0 & 0.97 \\
\hline Senate committee & 0.275 & 0.447 & 0 & 1 \\
\hline ECPA & 0.653 & 0.477 & 0 & 1 \\
\hline \multicolumn{5}{|l|}{ Intervenor Vars. } \\
\hline Power & 0.857 & 1.353 & 0 & 11 \\
\hline Environmental & 1.943 & 0.907 & 0 & 6 \\
\hline Sportfishing & 2.277 & 1.412 & 0 & 8.4 \\
\hline Boating & 0.495 & 1.066 & 0 & 5.5 \\
\hline Historical & 0.807 & 1.035 & 0 & 6 \\
\hline Endangered species & 2.186 & 1.243 & 0 & 8.4 \\
\hline Water quality & 2.087 & 1.250 & 0 & 10 \\
\hline Recreation & 0.860 & 1.223 & 0 & 7.667 \\
\hline
\end{tabular}

$\mathrm{LCV}=$ League of Conservation Voters; ECPA = Electric Consumers Protection Act.

Our first hypothesis, that of interest group effects, is tested with the intervenor information recorded in each project's docket sheet. A docket is a chronological listing of all of the official paperwork, filed through FERC, regarding a project's hydroelectric relicensing process. It begins the day a relicensing application is filed and records, throughout the relicensing process, all of the comments and protests submitted by interest groups and affected parties. From these dockets, lists were tabulated, for each project, of all of the individual interest groups involved in the relicensing processes (see Table 2 for representative examples), as well as the number of times each particular group 


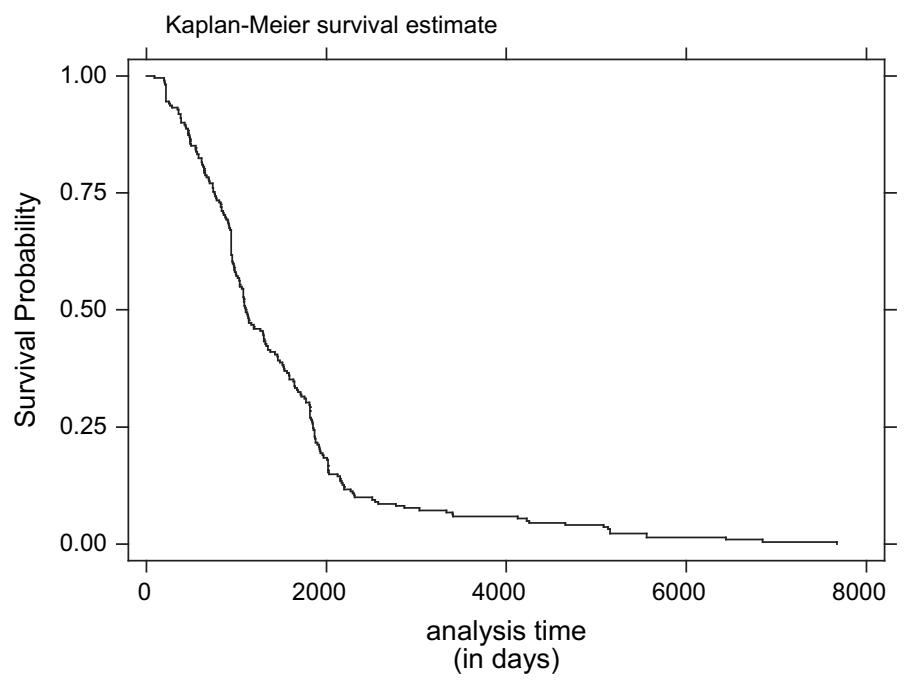

Figure 1. Kaplan-Meier Survival Estimate.

chose to comment (in order to capture the degree of their involvement, and not simply their presence). ${ }^{18}$

This count data were first grouped into two variables: comments by power interests and comments by environmental interests. In later regressions this information was further broken down in order to achieve a higher degree of detail concerning the potential effects of particular advocacy types.

It is worthwhile to alert the reader early to the method by which the intervenor data were broken down when disaggregated by advocacy type. A few of the intervenors (though not enough to justify additional categories) were known to advocate on behalf of multiple interests (the national organization American Rivers, for example, is concerned with endangered species, water supply, and sportfishing issues). When the data were tabulated, these multiadvocacy intervenors were counted in each of the categories to which their interests applied. Due to this construction, the reader should be forewarned of a degree of multicollinearity built into the data set - the author assumed that this negative was worth the additional degree of disaggregated interest group effect information it provided.

The ability of the legislature to affect FERC's bureaucratic process was tested in three ways. First, the average League of Conservation Voters score

18. All of the following intervenor variables were calculated for each project as: [total number of comments for the advocacy type / total number of specific groups involved], which equals the average number of comments per interest group. The means in Table 3 can be less than 1 because, on some projects, certain categories of intervenors (e.g., boating) chose not to comment at all. Note also that mass letter-writing campaigns (such as may have been instituted by groups such as the Sierra Club) do not skew our results, as single letters coming from individuals are not recognized as a distinct "interest group" in our data set. Finally, the power advocacy variable includes comments from outside hydropower interest groups as well as comments of a substantive nature from the dam owner. 
( $L C V$ score) for the two senators in Congress from the state within which a project is located, in the year that the project came up for relicensing, was included as a proxy for the "congressional mood" in Congress at the time of relicensing. The idea is that, at different times or in different political environments, pressure from congressional representatives may have a varying effect on the regulatory agency. Specifically, if the mood in Congress is heavily Democratic and pro-environmental, then congressional pressure in support of environmental benefits, in such a setting, would have more of a hastening effect on the regulatory agency than if Congress were at that time dominated by hydropowersupporting Republicans. The LCV score is a ranking from 0 to 1 of environmental sensitivity ( 0 being none, 1 implying extreme environmental sensitivity), gleaned from the past voting records on environmental issues of each elected senator (traditionally, Republicans have had lower LCV scores than Democrats, and eastern states have had much higher scores than western ones). ${ }^{19}$ We would expect that as LCV score increases, if the legislature is effective, environmental pressure from Congress would hasten regulatory speeds.

We also include a dummy variable to test for effective legislative pressure from the Senate oversight committee (Senate committee). This variable indicates whether at least one of the senators in a project's state, at the time of relicensing, was a member of the committee in charge of overseeing FERC. According to congressional control theories of regulation, an individual senator who has direct congressional influence over FERC should be able to particularly influence the commission's regulatory decisions in his or her home state. While we predict that a more liberal Congress will, in the aggregate, seek relative regulatory haste, individual senators could use their influence in either direction. In fact, Stigler (1971) and Mayhew (1974) hypothesize that individual senators respond more to concentrated interests, which in this case is the delay-seeking hydropower interest groups. Thus, if this variable is significant in the final regression results, we do not predict in which direction it will affect relicensing processing times.

Finally we include a dummy variable, $E C P A$, which indicates whether a project was relicensed after the implementation date of the ECPA amendments (January 2, 1990). Since the initial years subsequent to any new legislative mandate involve a period of administrative adaptation, we might expect to find a coefficient on this covariate that implies regulatory delay. At the same time, the ECPA amendments were designed to increase FERC's propensity to deliver environmentally friendly regulation, as well as to expand the role of environmentally friendly intervenors in the relicensing process. For these reasons, we might expect to see a hastening of the relicensing process as a direct effect of this covariate. The apparent influence of this explanatory variable will be the net

19. To give a flavor, for the year-2000 scorecard, Republicans in the Senate averaged an LCV score of 0.12 , while Democrats averaged 0.79. Meanwhile, eastern states posted the highest environmental scores - Rhode Island, 1; Connecticut and New Jersey, 0.91; Vermont and Massachusetts, 0.88 - and western states the lowest, with Idaho, Wyoming, Alaska, Utah, and Oklahoma all posting scores of 0.0 . 
effect of compound and competing influences - processing legitimacy versus intervenor interests - so the final outcome is difficult to predict a priori.

In order to test the workload hypothesis, in all of its various manifestations, we have included in our empirical analysis a host of descriptive project variables. To control first for the aggregate number of projects FERC has to process, other projects is a count variable indicating the number of other projects concurrently under review at the regional office of a project applicant, in the year that it applies for a relicense. If the coefficient on other projects is significant, delay in relicensing times would, at least partially, be influenced by aggregate regional project workload, implying that a greater number of projects increases the time to relicense.

NY office, AT office, PO office, and SF office are dummy variables controlling for the office at which a project was relicensed (respectively, New York, Atlanta, Portland, and San Francisco, with Chicago being the omitted category). If a project application's relicensing process is homogeneous across offices, these variables should be insignificant.

Ideally, more detailed data would have been beneficial to test the workload hypothesis across regional offices. Variables on appropriations per office, employees per office, or even employee hours per project would have added greater clarity to this discussion. Unfortunately, data at this level of detail were unavailable. Most governmental agencies update current-year resources but do not retain historical records. For this reason we took advantage of the cruder measures of workload across regional offices, as detailed above.

Next, to test for influences in workload for a particular project stemming from project size, we have included a few dam descriptive covariates. Dam height, measured in feet, is our first indicator of the size of the relevant project. $K W$, which measures the available $\mathrm{kW}$ production capacity at a project, is a second size indicator. Gross storage measures the at-site maximum storage capacity in acre-feet of a project's reservoir. Drainage area defines the maximum area, in square miles, above the control works of the dam. The effect of these variables on time to relicense will give us an indication as to whether larger projects are somehow treated differently by FERC in the relicensing process. If the coefficients signify delay, this will imply that larger dams take longer to process and increase the time to relicense.

Dam year is an additional dam descriptive variable, consisting of the last two digits of the year in which the earliest on-site project was built. ${ }^{20}$ Therefore, the larger the value of this variable, the newer the dam. If this variable should turn out to be significant in increasing delay, it could indicate a form of de facto grandfathering for older plants.

The variables used to indicate degree of project complexity, or contention for the allocative uses of a project's waters, are endangered river, endangered species, run-of-river, electricity price, private owner, multiple owner, and total requirements. Endangered river is a dummy variable used to indicate the base

20. Some projects in fact consist of more than one dam. In such an instance, dam year is the age of the oldest dam on site. Similarly, dam height is a measure of the tallest dam on site. 
environmental health of a river on which a project is located. It indicates whether the river is listed as threatened/endangered (as assessed by American Rivers, www.amrivers.org) in the year the project applied for a relicense. Endangered species gives the recorded number of federally listed endangered species for a project's county. Run-of-river is a dummy variable indicating whether a dam's mode of operation is run-of-river, storage (i.e., peaking), or gravity diversion. Run-of-river is the most environmentally friendly method of generating electricity, while storage and gravity produce more electricity and at more valuable times, but also at greater environmental harm. These three variables together give an indication of the environmental status of a river and may capture whether environmental interest groups would be taking a keen interest in the project. If these variables are significant, then we know that FERC is alerted to the possible environmental allocative needs of a river when making its relicensing decisions. If they are significant and lead to delay, this implies that the effect of their workload burden is dominant in affecting relicensing times; if significant and implying a hastening effect, that their political motivations override any workload burden in affecting processing times.

Representing the opposite spectrum of allocative uses of a project's waters, we have electricity price, private owner, and multiple owner. Electricity price is the average residential price of electricity (in cents) per kilowatt-hour for the state in which the project is located in the year it applied for a relicense (deflated by the Consumer Price Index, base year 1970). The more expensive the electricity, the more valuable the allocative use of the project's water toward hydroelectricity production. Private owner is a dummy variable indicating whether the owner of the project is a private utility company, a municipality, a nonutility, or a cooperative (e.g., a Native American tribe). Multiple owner is, as well as a firm-ownership indicator, a dummy variable proxying for size of the firm owner. Private firms that generally own more than one large revenue-generating project are often heavily invested in hydroelectric generation and may be even more strongly opposed than other types of owners to alternative allocative uses of the project's waters. These variables may also capture both workload and political pressure effects on the regulatory process, but as both of these would work to increase duration, we would expect the coefficients on all of these variables to imply delay.

Finally, total requirements is an indicator for variety. ${ }^{21}$ Total requirements is a count variable of the total number of environmental requirements mandated by FERC per relicense application. The larger total requirements is the more allocative uses for the river FERC has attempted to accommodate when issuing its project relicense. If the variable's effect is significant and delaying, then project complexity can be interpreted as a workload variable that is effective in altering processing times. ${ }^{22}$

21. Due to potential endogeneity concerns, column 3 of Table 4 gives the results of a duration model absent total requirements. Little of significance changes, but both are discussed in the Results section for thorough exposition.

22. Additional variety proxies would have been useful, but data limitations prevented discovery of such additional variables. 


\section{Empirical Approach}

This paper seeks to understand the determinants of time to relicense, or duration $(T)$, of a hydroelectric relicense in the FERC regulatory process. The dependent variable of interest could be analyzed with traditional ordinary least squares (OLS), but we believe that duration analysis is a superior approach. ${ }^{23}$ In traditional regression analysis a normal distribution is generally assumed for the dependent variable, while duration variables are positive by construction. A normal distribution that can take on negative values is therefore inappropriate.

Instead we assume a continuous probability distribution $f(t)$, where $t$ is a realization of positive duration, $T$. The cumulative probability is $F(t)=$ $\int_{0}^{t} f(s) d s=\operatorname{Pr}(T \leq t)$ and the survival function, or the probability that time to relicense is of length at least $t$ is $S(t)=1-F(t)=\operatorname{Pr}(T \geq t)$.

With this setup, we can isolate the piece of information that is of particular interest: Given that a hydroelectric relicensing process has lasted until time $t$, what is the probability that FERC will finally issue its regulatory decision, given that it has not yet done so? The hazard rate, a function that describes the instantaneous probability of completing a given duration spell at time $t$, given that the relicensing process has reached time $t$, is the answer to this question, and it is this function that we directly estimate in our empirical analysis. Letting $\lambda(t)$ denote the hazard rate,

$\lambda(t)=\lim _{\Delta \rightarrow 0} \frac{\operatorname{Pr}(t \leq T \leq t+\Delta \mid T \geq t)}{\Delta}=\frac{f(t)}{S(t)}$.

The functional form chosen for the hazard rate is a Weibull specification: ${ }^{24}$

$\lambda(t)=\exp (\beta x) \alpha t^{\alpha-1}$

where the coefficients, $\beta$, capture the effects of the observed covariates, $x$, on the hazard function, and the value of $\alpha$ determines the direction of duration dependence. ${ }^{25}$ The estimable equation in this study is:

$$
\begin{gathered}
\exp (\beta x) \equiv \exp \{(\text { intervenor variables, } \text { political variables, } \\
\text { workload variables }) \beta\}
\end{gathered}
$$

23. For comparison, OLS was run as well and the results were comparable to the duration analysis. A Shapiro-Wilk test for normality proved that the OLS error terms were not normal, giving further support for the appropriateness of a duration model.

24. This specification provided the best fit. It also does not assume a direction for what is called "duration dependence," the idea that as a relicense reaches a particular point, it is more (positive duration dependence) or less (negative duration dependence) likely to then reach completion. In the hydroelectric relicensing context, it is difficult to specify a priori the direction of this duration dependence, so the flexible function form of a Weibull specification is useful. Results with the Weibull specification also proved similar to those from "semi-parametric" specifications, including the Cox proportional hazards model.

25. If $\alpha$ is less (greater) than 1 , then there is negative (positive) duration dependence. 
One issue of particular concern is the potential endogeneity of intervenor comments. If we assume that interest group decisions regarding comments submitted to FERC are made in a simultaneous game setting, where the ultimate regulatory outcome rests on the equilibrium level of these pressure functions and interest groups are not submitting comments in a strategic setting, then we do not have to worry about endogeneity and can assume that intervenor comments are predetermined in the relicensing process. Such an assumption would be more reasonable if the length of time given interest groups to comment in the relicensing procedure were limited to six months, or perhaps one year, and when delay exists in the official publication of these comments. In this context, however, intervenor comments are accepted and published in the FERC docket sheet throughout the length of the (sometimes lengthy) relicensing process. Assuming away endogeneity of intervenor comments may be something of a stretch. We can take heart, however, in recent research that bolsters such an assumption: In a study of intervenor group comments received by the EPA during consideration of additions to the U.S. endangered species list, Ando (2001) specifically asks the question whether interest group comments are submitted strategically, whereby the pressure from one interest group increases or decreases with the pressure intensity coming from an opposing group, or whether interest group comments are instead motivated by benefit/cost considerations that can accrue to the groups as a result of the final regulatory decision. Her results confirm that interest groups do not appear to act strategically, but instead respond to internal benefit/cost calculations.

Further support for the decision not to be overly concerned with potential endogeneity of intervenor comments comes from the empirical results detailed in the next section. Briefly, we find that pressure from interest groups is not always in the direction expected; specifically, not all environmental interest groups seek to hasten the relicensing process; instead, even environmental advocacy groups sometimes seek to slow the relicensing process down. This implies that not all "environmental" interest groups are diametrically opposed to all "hydropower" interest groups, and so the motivation for strategic behavior is less straightforward. When many of the involved interest groups are not measuring their effects on the process relative to a single opposing benchmark, it is harder to conceive of in what sense their comments can be seen as strategic. Such results, therefore, give further weight to the conclusion that endogeneity is likely not an issue for concern in this analysis.

\section{Results}

Table 4 gives the results of our duration analyses on time to relicense. The first column presents the hazard ratios for a model in which the intervenor information is broken down into two categories: power and environmental. The hazard ratios tell us how each particular variable contributes to duration. If the ratio is less than 1 , this indicates a lengthening of the process. If the ratio is greater than 1 , it implies that a particular variable tends to hasten the 
Table 4. Duration Model on Time to Relicense

\begin{tabular}{|c|c|c|c|c|}
\hline Variable & $\begin{array}{c}1 \\
H R\end{array}$ & $\begin{array}{c}2 \\
H R\end{array}$ & $\begin{array}{c}3 \\
H R\end{array}$ & Aux. $R^{2}$ \\
\hline \multicolumn{5}{|l|}{ Constant } \\
\hline \multicolumn{5}{|l|}{ Workload Vars. } \\
\hline Other Projects & $\begin{array}{c}1.002 \\
(0.004)\end{array}$ & $\begin{array}{c}1.006 \\
(0.004)\end{array}$ & $\begin{array}{c}1.007 \\
(0.004)\end{array}$ & 0.237 \\
\hline New York office & $\begin{array}{l}2.391^{\star \star *} \\
(0.695)\end{array}$ & $\begin{array}{l}2.033^{\star *} \\
(0.597)\end{array}$ & $\begin{array}{l}2.102^{\star \star \star} \\
(0.608)\end{array}$ & 0.246 \\
\hline Atlanta office & $\begin{array}{l}2.146^{* *} \\
(0.712)\end{array}$ & $\begin{array}{l}2.365^{\star *} \\
(0.812)\end{array}$ & $\begin{array}{l}2.527^{\star * *} \\
(0.898)\end{array}$ & 0.250 \\
\hline Portland, OR, office & $\begin{array}{c}2.209^{*} \\
(0.967)\end{array}$ & $\begin{array}{l}2.362^{\star *} \\
(1.038)\end{array}$ & $\begin{array}{c}1.903 \\
(0.858)\end{array}$ & 0.229 \\
\hline San Francisco office & $\begin{array}{l}0.335^{\star * *} \\
(0.137)\end{array}$ & $\begin{array}{l}0.231^{\text {*** }} \\
(0.103)\end{array}$ & $\begin{array}{l}0.331^{\star *} \\
(0.146)\end{array}$ & 0.226 \\
\hline Dam height $/ 10^{3}$ & $\begin{array}{l}1.00 \\
(2.55)\end{array}$ & $\begin{array}{l}1.002^{(\mathrm{A})} \\
(2.678)\end{array}$ & $\begin{array}{c}0.997 \\
(2.427)\end{array}$ & \\
\hline $\mathrm{kW} / 10^{6}$ & $\begin{array}{c}1.00 \\
(2.92)\end{array}$ & $\begin{array}{l}1.00^{\left(A^{\prime}\right)} \\
(3.12)\end{array}$ & $\begin{array}{l}1.00 \\
(2.93)\end{array}$ & \\
\hline Gross storage $/ 10^{6}$ & $\begin{array}{l}1.00^{\star \star \star} \\
(0.335)\end{array}$ & $\begin{array}{l}1.00^{\star \star \star(A)} \\
(0.348)\end{array}$ & $\begin{array}{l}1.00^{\star \star \star} \\
(0.293)\end{array}$ & \\
\hline Drainage area $/ 10^{3}$ & $\begin{array}{l}1.00^{\star * *} \\
(0.011)\end{array}$ & $\begin{array}{l}1.00^{*(\mathrm{~A})} \\
(0.011)\end{array}$ & $\begin{array}{c}1.00^{* \star *} \\
(0.011)\end{array}$ & \\
\hline Dam year & $\begin{array}{c}0.997 \\
(0.004)\end{array}$ & $\begin{array}{l}0.992^{* *} \\
(0.004)\end{array}$ & $\begin{array}{c}0.995 \\
(0.004)\end{array}$ & \\
\hline Endangered river & $\begin{array}{c}1.399 \\
(0.321)\end{array}$ & $\begin{array}{l}1.215^{(\mathrm{B})} \\
(0.286)\end{array}$ & $\begin{array}{c}0.877 \\
(0.206)\end{array}$ & \\
\hline Endangered species & $\begin{array}{c}1.031 \\
(0.026)\end{array}$ & $\begin{array}{l}1.042^{(\mathrm{B})} \\
(0.028)\end{array}$ & $\begin{array}{c}1.015 \\
(0.029)\end{array}$ & \\
\hline Run-of-river & $\begin{array}{c}0.850 \\
(0.163)\end{array}$ & $\begin{array}{l}1.021^{(B)} \\
(0.202)\end{array}$ & $\begin{array}{c}1.037 \\
(0.196)\end{array}$ & \\
\hline Electricity price & $\begin{array}{l}0.814^{\star \star *} \\
(0.064)\end{array}$ & $\begin{array}{l}0.803^{* * *(C)} \\
(0.064)\end{array}$ & $\begin{array}{l}0.783^{\star * *} \\
(0.062)\end{array}$ & \\
\hline Private owner & $\begin{array}{l}0.528^{\star \star \star} \\
(0.099)\end{array}$ & $\begin{array}{l}0.567^{\star * *(C)} \\
(0.111)\end{array}$ & $\begin{array}{l}0.590^{\star * \star} \\
(0.113)\end{array}$ & \\
\hline Multiple owner & $\begin{array}{c}1.007 \\
(0.210)\end{array}$ & $\begin{array}{l}1.142^{(\mathrm{C})} \\
(0.247)\end{array}$ & $\begin{array}{c}1.280 \\
(0.278)\end{array}$ & \\
\hline Total requirements & $\begin{array}{l}0.885^{\text {** }} \\
(0.019)\end{array}$ & $\begin{array}{l}0.895^{\star * *} \\
(0.020)\end{array}$ & & \\
\hline Political Vars. & & & & \\
\hline LCV score & $\begin{array}{l}2.721^{\star \star} \\
(1.323)\end{array}$ & $\begin{array}{l}5.474^{\star \star \star(D)} \\
(2.883)\end{array}$ & $\begin{array}{l}3.851^{\star *} \\
(2.048)\end{array}$ & \\
\hline Senate committee & $\begin{array}{l}0.615^{\star *} \\
(0.144)\end{array}$ & $\begin{array}{l}0.737^{(\mathrm{D})} \\
(0.171)\end{array}$ & $\begin{array}{c}0.687 \\
(0.164)\end{array}$ & \\
\hline ECPA & $\begin{array}{l}2.122^{\star \star *} \\
(0.507)\end{array}$ & $\begin{array}{l}1.928^{* * *} \\
(0.477)\end{array}$ & $\begin{array}{c}1.126 \\
(0.256)\end{array}$ & \\
\hline
\end{tabular}




\begin{tabular}{|c|c|c|c|c|}
\hline Variable & $\begin{array}{c}1 \\
H R\end{array}$ & $\begin{array}{c}2 \\
H R\end{array}$ & $\begin{array}{c}3 \\
H R\end{array}$ & Aux. $R^{2}$ \\
\hline \multicolumn{5}{|l|}{ Intervenor Vars. } \\
\hline Power & $\begin{array}{l}0.724^{\star * *} \\
(0.050)\end{array}$ & $\begin{array}{l}0.672^{* * *} \\
(0.051)\end{array}$ & $\begin{array}{l}0.663^{* \star *} \\
(0.051)\end{array}$ & \\
\hline Environmental & $\begin{array}{l}0.755^{\star \star \star} \\
(0.066)\end{array}$ & & & \\
\hline Sportfishing & & 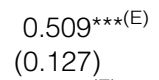 & $\begin{array}{l}0.423^{\star \star \star} \\
(0.107)\end{array}$ & \\
\hline Boating & & $\begin{array}{l}1.124^{(\mathrm{E})} \\
(0.088)\end{array}$ & $\begin{array}{c}1.121 \\
(0.088)\end{array}$ & \\
\hline Historical & & $\begin{array}{l}0.793^{* *(E)} \\
(0.083)\end{array}$ & $\begin{array}{l}0.754^{\star * *} \\
(0.078)\end{array}$ & \\
\hline Endangered species & & $\begin{array}{l}1.744^{\star(E)} \\
(0.530)\end{array}$ & $\begin{array}{l}2.091^{\star *} \\
(0.643)\end{array}$ & \\
\hline Water quality & & $\begin{array}{l}1.002^{(\mathrm{E})} \\
(0.142)\end{array}$ & $\begin{array}{c}0.974 \\
(0.144)\end{array}$ & \\
\hline Recreation & & $\begin{array}{l}1.049^{(E)} \\
(0.073)\end{array}$ & $\begin{array}{c}0.964 \\
(0.073)\end{array}$ & \\
\hline
\end{tabular}

$\mathrm{LCV}=$ League of Conservation Voters; ECPA = Electric Consumers Protection Act.

$$
p=2.122 \quad p=2.215 \quad p=2.113
$$

\footnotetext{
(A) Joint significance test: $\mathrm{Chi}^{2}(4)=34.08$, Prob $>\mathrm{Chi}^{2}=0.0000^{\star * *}$

(B) Joint significance test: $\mathrm{Chi}^{2}(3)=3.56$, Prob $^{2} \mathrm{Chi}^{2}=0.3133$

(C) Joint significance test: $\mathrm{Chi}^{2}(3)=20.15$, Prob $>\mathrm{Chi}^{2}=0.0002^{\star \star \star}$

(D) Joint significance test: Chi(2) $=18.03$, Prob $>\mathrm{Chi}^{2}=0.0001^{\star \star *}$

(E) Joint significance test: $\mathrm{Chi}^{2}(6)=25.72$, Prob $>\mathrm{Chi}^{2}=0.0003^{\star \star \star}$
}

Note that the hazard ratios on dam height, kW, gross storage, and drainage area approach 1 due to rounding effects from the rather large coefficients.

relicensing process. ${ }^{26}$ The second column is a duration model including the same workload and political variables as column 1, but with the intervenor information broken down further by detailed advocacy type. Column 3, finally, presents the detailed duration model of column 2, but without the total requirements variable, as a check on endogeneity. As the results for the workload and political variables are similar across all specifications, discussion of these variables will not generally be referenced to a particular column.

Our first hypothesis was that hydropower interests delayed relicensing times, while environmental interests hastened processing times. Looking at the intervenor involvement variables, what stands out in column 1 is the fact that both the power and environmental advocacy groups have the effect of delaying the relicensing process. Dam owners and power intervenors may in general wish to delay the relicensing process if doing so amounts to

26. It is possible to determine more specific size effects attributable to each hazard ratio by transforming the hazard ratios into their underlying hazard function coefficients ( as is done in Table 5), so that a $1 \%$ increase in variable $x$ implies a percentage increase to the hazard function equal to the given coefficient, $\beta$, which then translates into a $\beta \times p$ percent effect on the median time to relicense. However, directional effects are of primary interest in this analysis. 
a postponement of costly environmental mitigation requirements that go along with a relicense. The longer the delay, the greater the chance of avoiding the costly requirements altogether - but if nothing else, delay will certainly subject these costs to greater discounting. Not all dams will require costly relicensing requirements, and dam owners as business owners also dislike the uncertainty that accompanies an unresolved relicensing procedure, but as the threat of costly environmental requirements grows, so does the incentive to delay the final outcome. We would thus expect the hydropower coalition, whose financial interests are constrained by relicenses with costly environmental mitigation requirements, to seek to delay the relicensing process. It is the similar effect of the environmental coalition that is surprising. The benefit/cost motivation of the environmental interest groups is to speed up the relicensing process, because the sooner a relicense is issued, along with its accompanying environmental mandates, the greater the probability of saving, or even promoting, such assets as healthy fishery resources for a river. This can be translated into monetary benefits for commercial fishers, recreational groups, guides and outfitters, or other interested parties who rely on healthy fish stocks for their businesses. What we find, however, is that the effect of environmental interest groups works to delay the relicensing process overall. Either the environmental interest groups are unaware of the costs they incur by delaying the relicensing process, or, more likely, their own interests in the regulatory process are not as homogeneous as it would at first appear.

The environmental interest groups that tend to get involved in any relicensing process are in fact composed of a wide variety of interests, from fishers to whitewater rafters to campers and hunters, and more. In order to explore the possibility that the environmental coalition may not be seeking homogeneous regulatory results, column 2 presents the results of a duration analysis in which the intervenor information is disaggregated further into specific cohorts. Of the six environmental advocacy groups presented in column 2 (sportfishing, boating, historical, endangered species, water quality, and recreation), only three are significant: sportfishing, historical, and endangered species. The sportfishing and historical hazard ratios remain less than 1, implying that the effect of comments from these interest groups is indeed to slow, not hasten, the relicensing process. Sportfishers, for example, who for years have profitably enjoyed the enormous reservoirs created behind large dams, do not appear to have an interest in tearing them down. Only the endangered species advocacy group has a significant hazard ratio that is greater than 1 , as we would have predicted a priori. The evidence from this desegregated duration analysis provides support for the notion that the environmental interest groups involved in the hydroelectric dam relicensing process have heterogeneous policy goals. As is commonly done in the media today, viewing the debate over reform of the hydroelectric relicensing process as "hydropower" versus "the environment" is simplistic and fundamentally incorrect, implying that the policy reform now being debated in Congress to reduce delay in hydroelectric licensing may not pass because, in part, the "environmental coalition" may not be as cohesive in interests as initially supposed. 
The results from column 2 lead us to ask the concomitant question: Why those three? What is the explanation for why sportfishing, historical, and endangered species interests are significant in effecting FERC's relicensing process, while boating, water quality, and recreation interests are not? Once conceivable explanation is that particular aims in the regulatory process have preferential priority with the regulator, whether for political, public relations, or simply personal reasons. Saving fishery resources, for example, may have greater public relations resonance than modifying reservoir turbidity. ${ }^{27}$ This preferential treatment for certain advocacy types would imply that comments by those interest groups that support them would have greater resonance than comments in support of less preferred advocacy interests. FERC may be responding to the current policy vogue when assessing the weight of particular intervenor comments.

A second explanation may be that the timing and outcome variables of FERC's relicensing decision are not entirely independent. Some environmental groups may be willing to trade increased regulatory speed for improved, or even additional, final environmental mitigating requirements. Only when the benefit of increased speed is greater than the benefit of added regulatory outcomes should we expect to see environmental interest groups actively seeking to hasten the relicensing process. Indeed, the interest group with the greatest need for speed over outcome (because of the possibility of species extinction), endangered species, is robustly significant in hastening the relicensing process.

Yet a third explanation is that FERC remains independently biased toward delay of the relicensing process and therefore responds primarily to those comments that seek a slowing down of it. Whether or not FERC is adequately addressing contemporary environmental concerns remains an issue. The ECPA of 1986, for example, was a legislative attempt to instill environmental concerns more prominently into FERC's objective function, because the perception was that the commission was not doing so on its own. DeShazo and Kosnik (2003) investigate the impact of this legislation (along with other factors) on FERC's final environmental mitigation requirements, and while it appears that FERC has attempted in recent years to alter its pro-hydropower reputation by balancing regulatory outcomes more equally between power and nonpower objectives, this duration analysis could be interpreted as showing that even while regulatory outcomes may be shifting toward a more balanced approach, the regulatory process itself, and particularly the length of time that the regulatory process takes, is still tilted in favor of delay, which benefits primarily the hydropower industry.

Turning to the legislative variables in our analysis, the hazard ratio corresponding to LCV score is significant and substantially greater than 1 , indicating

27. A parallel can be made with implementation of the ESA. Yaffee (1982) found that mammals (such as wolves and bears) are much more likely to be protected as endangered and to have effective support in the listing process because they are seen as more "popular" than, for example, mollusks (such as snails). 
that as environmental sensitivity in Congress grows, the proclivity for pressure on the relicensing agency to speed up the relicensing process increases, and at a rate larger than the effect of many of the other variables in this analysis. Sympathy of Congress to environmental interests appears to be one of the most influential factors affecting hydroelectric dam relicensing process times. This result gives weight to congressional dominance theories of regulatory behavior, and also implies that in the current Republican-dominated Congress, passage of Title III reform has less of a chance at passage.

Surprisingly, Senate committee, the dummy variable indicating senate representation on FERC's oversight committee is generally insignificant, implying, in contrast to Weingast and Moran (1983), that individual congressmen overseeing FERC have no influence on the regulatory process, or that their influence is not captured by any particular interest group in a single significant direction.

The legislative variable $E C P A$, dummying for passage of the proenvironmental 1986 FPA amendments, bears an estimated hazard ratio that is significant and greater than $1 .^{28}$ If the hazard ratio on this covariate had been less than 1, it would have indicated that legislative changes imply overwhelmingly significant workload burdens on FERC. Instead, its large positive significance implies that FERC has responded to the legislation's intent, without dominance from its workload burden. The results from this variable, therefore, give even greater weight to congressional dominance theories of regulatory control and decrease support for the notion of a hydropower bias in FERC's regulatory process. These results imply that reform of the hydroelectric relicensing process is not dead in the water if the legislature, which in the past has been able to affect regulatory speed, can dominate the mostly delaying effects of outside interest groups.

Our final hypothesis was that workload burden delayed relicensing processing times. The first thing to notice in this regard is that other projects, the variable created to control for gross workload, is not individually significant, implying that an increase in the total number of projects to process, per regional office, does not affect time to license. FERC is apparently able to compensate for projects that begin the relicensing process in heavy gross workload periods, perhaps through increased staffing (which we were unfortunately unable to test directly), or a lower level of necessary requirements to process per application. Whatever the reason, the number of concurrent projects under process at the time a new project comes under review does not appear to affect the new project's time to license. Surprisingly, however, the dummy variables for regional office are all significant, implying that the relicensing process is not homogeneous across offices. The hazard ratios on the dummy variables for the New York, Atlanta, and Portland offices are all greater than 1, while the San Francisco office has the only hazard ratio that is less than 1. Exactly why the

28. To address any collinearity concerns among the political variables, auxiliary regressions were run which indicate: $L C V \_S C O R E$ Adj. $\mathrm{R}^{2}=0.276$, SENATE_COMMITTEE Adj. $\mathrm{R}^{2}=0.283$, and $E C P A$ Adj. $\mathrm{R}^{2}=0.013$. 
processing times should vary across regional offices is unclear, especially as the gross workload project variable is insignificant. It may be that these variables are significant because they are capturing some omitted office workload variables not available due to the poor data collection across regional offices. $^{29}$

Other aspects of workload, however, do have a significant effect on processing times. Of the project size indicator variables (dam height, $K W$, gross storage, drainage area), half are significant (and they are all jointly significant), ${ }^{30}$ and both of these are greater than 1, indicating that larger and perhaps more technically complex dams require greater processing time by FERC. Note, however, that interpreting these hazard ratios as indicators that FERC spends more time processing larger dams because of their increased analytical demands is not straightforward. It may be true that larger projects entail more studies, assessments, and tests, which genuinely leads to longer processing times; but it could also be true that larger, more revenue generating projects are being delayed in the relicensing process due to an underlying political bias to preserve their working status as long as possible, irrespective of the effects on the environment. FERC has long been criticized for regulating too heavily in favor of hydroelectric power production, and too frequently downplaying environmental concerns. FERC's slowing of the relicensing process for larger dam projects could be an indication of the commission's alleged bias in favor of the hydroelectric industry, which wants to delay relicensing on its largest power-producing projects. $^{31}$

Due to these equally valid divergent interpretations of the delaying effects of these case-specific variables, this study refrains from making any normative judgments on the hazard ratios of the workload variables. Lengthy processing times may be seen as costly in terms of resources expended, time spent waiting for an outcome, and subsequent actions put on hold until the final outcome is confirmed, but at the same time, delay may be broadly beneficial if it adds to the political legitimacy of the ultimate outcome mandated. If the increased time involved in a regulatory process is not a mere stalling tactic ("paralysis by

29. Auxiliary regression results to identify whether the office dummy variables may be capturing some of the workload effect that OTHER_PROJECTS was intended to identify can be found in Table 4.

30. A joint significant test on the individually insignificant variables $D A M \_H E I G H T$ and $K W$, however, produces the following results: $\mathrm{Chi}^{2}(2)=1.48$, $\mathrm{Prob}>\mathrm{Chi}^{2}=0.478$. Auxiliary regressions to identify the most highly linearly related of these project size indicators indicate: DAM_HEIGHT Adj. $\mathrm{R}^{2}=0.634, K W$ Adj. $\mathrm{R}^{2}=0.705$, GROSS_STORAGE Adj. $\mathrm{R}^{2}=0.599, D R A I N A G E \_A R E A$ Adj. $R^{2}=0.334$.

31. To try to shed light on the possibility of an underlying hydropower political bias at FERC, a regression similar to column 1 was run, but including the following interaction terms: DamHeight $\times$ Power, $k W \times$ Power, GrossStorage $\times$ Power, DrainageArea $\times$ Power. Similarly, another regression was run excluding the intervenor comments completely to observe the effect this had on the workload variables. The interaction terms turned out to be insignificant and the hazard ratios of the workload variables without intervenor comments did not significantly alter. While interesting, these results fail to prove or disprove any potential FERC bias; they only eliminate the possibility that the bias, if it exists, stems from the political influence of the intervenors. 
analysis"), but is genuinely spent increasing the detail, technical expertise, or variety of preferences represented in the administrative process itself, then delay can serve the more broadly useful social goal of legitimizing the ultimate outcome of a mandate. Thus, while determining the existence of workload delay may be somewhat straightforward, making conclusions as to its value is not.

Dam year is insignificant in two out of the three specifications (in column 2 it is significant at the $5 \%$ level) and its hazard ratio is near 1 . It appears, therefore, that dam age has little, if any, effect on time to relicense. De facto grandfathering does not appear to occur in FERC's hydroelectric relicensing process.

Endangered river, endangered species, and run-of-river are all variables used to indicate the environmental health of a project. Projects in areas where a high number of species are endangered, or located on a river that is deemed threatened, should involve higher levels of contention surrounding the project relicense. A priori, the hazard ratios on these variables could turn out to be either less than 1 (as projects with poor health may require more detailed environmental assessments or other analytical reports ), or greater than 1 (if the political pressure to deal with environmentally endangered projects dominates). What we find instead is that none of these variables are individually (or jointly) significant at all, indicating either that the opposing forces reported above balance or that the timing of FERC's regulatory process is not responsive to the environmental health of a project in any way, a less intuitively appealing explanation. ${ }^{32}$

Electricity price, private owner, and multiple owner are three indicators of profitability of a hydroelectric project. Their hazard ratios, if significant, would be expected to be less than 1 (implying increased delay in the regulatory process), both because more profitable projects may imply greater administrative workload and because more profitable projects, similar to more environmentally potent projects, will likely garner higher levels of political contention. Indeed electricity price and private owner are both significant with hazard ratios less than 1, and all three variables are jointly significant.

The final project complexity indicator, total requirements, is significant and less than 1, as expected. As the number of mandates issued by FERC increases, so does the time to license, implying that each additional mandate requires a time investment by FERC to consider. ${ }^{33}$ Said another way, as the preference

32. Interaction terms were investigated here as well. A regression similar to column 1 was run but including Endangered River $\times$ Environmental, Endangered Species $\times$ Environmental, and Runof-River $\times$ Environmental. None of these interaction terms were significant either, again implying that if FERC is feeling any political pressure to speed up the relicensing process, it does not stem from interest group comments.

33. To allay any concerns regarding potential endogeneity effects of including total requirements in the model, column 3 of Table 4 presents a regression without the term. The only variable whose significance changes is that of the legislative variable, ECPA. This leads to an interesting result with respect to the regulatory process. Given a large number of total requirements, which tend to slow the relicensing process down, ECPA kicks in to speed things up. However, without the extra requirements, ECPA has no significant effect. Mutatis mutandis, ECPA is effective in speeding up the relicensing process only when there are a large number of requirements to consider. 
set for a project's allocative end uses increases, relicensing time increases as well. This argues that to some degree, delay exists for the benefit of all intervenors. By allowing relicensing time to increase as the number of interests involved increases, FERC allows a more thorough evaluation of each preference set presented, which ultimately lends greater legitimacy to the commission's final mandate.

\section{Conclusions}

This paper began with a search for the sources of regulatory delay in the hydroelectric dam relicensing process, in part in order to inform the current debate over this issue in Congress. The empirical results have found support for three hypotheses of regulatory action: regulatory capture theory, congressional dominance theory, and bureaucratic discretion theory.

In terms of regulatory capture theory, this analysis has found evidence that outside interest groups are significantly effective in influencing the timing of the regulatory process. Of particular interest is the result that the environmental interest groups represented in the process do not all seek to hasten the relicensing process, as opposed to the hydropower interests, which do in general appear to seek to slow it down. The "environmental lobby" consists of advocacy groups supporting a wide range of interests, some of which seek to slow the process down, others of which effect a speed- up in processing times. Not all of these particular interest groups are significant in effecting FERC's bureaucratic process either, leading to the conclusion that specific environmental goals hold sway with FERC either out of policy vogue or because the commission continues to pursue an alleged bias to slow the relicensing process down. A better understanding of why particular interest groups are more effective than others at influencing the regulatory process would be a fruitful area for future research.

This analysis also gives support to congressional dominance theories of regulatory action by finding that the degree of congressional sympathy for environmental goals affects the speed of the relicensing process, as can legislative amendments. In fact, coefficients on these variables are the largest in our analysis, suggesting that the degree of legislative influence on the bureaucratic process can dominate most other effects. With regard to hydroelectric dam relicensing, this implies that if Congress should truly put its weight behind any proposed reform, it has the legislative muscle to significantly affect the relicensing process.

And finally, this study has found evidence for bureaucratic discretion in the hydroelectric dam relicensing process in the significance of many of the casespecific workload variables. Larger dams that produce more valuable hydroelectric power take longer to process, while environmentally sensitive dams located on threatened rivers or in areas with a high number of endangered species are not speeded up. Whether this effect is due to pure administrative burden or is a result of an underlying political bias is indeterminate. Another useful area for further research would be to more adequately discern the 
motivation for the effect of these case-specific variables on the relicensing process. In terms of current policy, the results of these case-specific variables imply that a good predictor of whether or not a specific project will in fact encounter regulatory delay during the hydroelectric relicensing process is the size of the dam up for review and the value of the hydroelectric power that it produces.

Note that this introduces a social welfare trade-off for consumers of hydroelectric power - by delaying larger dams that produce expensive hydroelectric power, consumers are able to maintain current electricity rates, but at the cost of delayed environmental improvements. They may prefer cheap electricity to higher prices and more environmental controls, but rarely is this trade-off made explicit. ${ }^{34}$

Overall, this paper finds support for a number of current regulatory theories, including regulatory capture, legislative dominance, and theories of bureaucratic discretion. Similar to the finding by Olson (1995), no one theory appears to hold complete dominance over bureaucratic decision making. As those who are familiar with it know, the hydroelectric dam relicensing process is a complex procedure, reform of which will be very difficult. At the same time, the results from this paper imply that there are many avenues for reform worth exploring. If the speed of the relicensing process is affected by interest groups, the legislature, and bureaucratic agents themselves, proper reforms affecting any one of these dimensions may be effective. Table 5 provides some analysis to this effect, analyzing the substantive impacts of possible changes in the variables that affect the relicensing process. It appears, for example, that if Congress passed another legislative mandate similar to the ECPA, it would hasten relicensing times, but by only sixteen days. Alternatively, if interest groups increased their presence in the relicensing process, a $1 \%$ increase in the comments of the power, sportfishing, and historical interest groups together would slow relicensing times by more than a month; if they increased their presence by $5 \%$, this would slow the process by an additional five months. Another substantially effective variable is the mood factor of Congress; were Congress to become 5\% more liberal (as measured by LCV scores), relicensing times would be hastened by almost seven months. In 2000, Olson analyzed the impact on regulatory processing times of the recent introduction of user fees on the speed of drug approval rates by the FDA. By aligning the interest of drug companies to hasten the process with user fees that can be utilized by the FDA to reduce workload, reductions in processing times have exceeded analysts' most optimistic projections. Something similar may be possible one day for the federal hydroelectric dam relicensing process.

34. An ultimate determination of whether such a trade-off in any particular relicensing context raises or lowers consumer welfare would require an explicit valuation of the given environmental requirements - a thorny issue best left for future research endeavors. 
Table 5. Impact Analysis

\begin{tabular}{|c|c|c|c|c|}
\hline Variable & Coefficient & Effect on Median Time & $5 \% \uparrow$ & $20 \% \uparrow$ \\
\hline \multicolumn{5}{|l|}{ Workload Vars. } \\
\hline Other Projects & 0.006 & 0.147 & 0.734 & 2.937 \\
\hline New York office & 0.709 & 17.353 & & \\
\hline Atlanta office & 0.861 & 21.074 & & \\
\hline Portland, OR, office & 0.859 & 21.025 & & \\
\hline San Francisco office & -1.465 & -35.857 & & \\
\hline Dam height & 1.662 & 40.679 & 203.393 & 813.574 \\
\hline $\mathrm{kW} / 10^{3}$ & 1.5 & 36.714 & 183.568 & 734.273 \\
\hline Gross storage $/ 10^{3}$ & -1.25 & -30.595 & -152.973 & -611.894 \\
\hline Drainage area/ $10^{3}$ & -0.026 & -0.636 & -3.182 & -12.727 \\
\hline Dam year & -0.008 & -0.196 & -0.979 & -3.916 \\
\hline Endangered river & 0.195 & 4.77 & & \\
\hline Endangered species & 0.041 & 1.00 & 5.018 & 20.070 \\
\hline Run-of-river & 0.021 & 0.514 & & \\
\hline Electricity price & -0.22 & -5.385 & -26.923 & -107.693 \\
\hline Private owner & -0.568 & -13.902 & & \\
\hline Multiple owner & 0.133 & 3.255 & & \\
\hline Total requirements & -0.111 & -2.717 & -13.584 & -54.336 \\
\hline \multicolumn{5}{|l|}{ Political Vars. } \\
\hline LCV score & 1.7 & 41.609 & 208.044 & 832.176 \\
\hline Senate committee & -0.305 & -7.465 & & \\
\hline ECPA & 0.656 & 16.056 & & \\
\hline \multicolumn{5}{|l|}{ Intervenor Vars. } \\
\hline Power & -0.398 & -9.741 & -48.707 & -194.827 \\
\hline \multicolumn{5}{|l|}{ Environmental } \\
\hline Sportfishing & -0.676 & -16.546 & -82.728 & -330.912 \\
\hline Boating & 0.117 & 2.864 & 14.318 & 57.273 \\
\hline Historical & -0.232 & -5.678 & -28.392 & -113.567 \\
\hline Endangered species & 0.556 & 13.609 & 68.043 & 272.170 \\
\hline Water quality & 0.002 & 0.049 & 0.245 & 0.979 \\
\hline Recreation & 0.047 & 1.150 & 5.752 & 23.007 \\
\hline
\end{tabular}

$\mathrm{LCV}=$ League of Conservation Voters; ECPA = Electric Consumers Protection Act.

The "Coefficient" column is a transformation of the hazard ratio into its underlying hazard function coefficient.

\section{References}

Ando, Amy Whritenour. 1999. "Waiting to Be Protected Under the Endangered Species Act: The Political Economy of Regulatory Delay," 42 Journal of Law and Economics 29-60.

- 2001. "Economies of Scope in Endangered-Species Protection: Evidence from InterestGroup Behavior," 41 Journal of Environmental Economics and Management 312-32.

Bartel, Ann P., and Lacy Glenn Thomas. 1987. "Predation Through Regulation: The Wage and Profit Effects of the Occupational Safety and Health Administration and the Environmental Protection Agency," 30 Journal of Law and Economics 239-64.

Becker, Gary S. 1983. "The Theory of Competition Among Pressure Group for Political Influence," 98 Quarterly Journal of Economics 371-400.

Carpenter, Daniel P. 2002. "Groups, the Media, Agency Waiting Costs, and FDA Drug Approval," 46 American Journal of Political Science 490-505.

Crone, Lisa. and John Tschirhart. 1998. "Separating Economic from Political Influences on Government Decisions," 35 Journal of Economic Behavior and Organization 405-25. 
Cropper, Maureen L., William N. Evans, Stephen J. Berardi, Maria M. Ducla-Soares, and Paul R. Portney. 1992. "The Determinants of Pesticide Regulation: A Statistical Analysis of EPA Decision Making," 100 Journal of Political Economy 175-97.

DeShazo, J.R., and Lea-Rachel Kosnik. 2003. "Integrating Interest Groups and Legislators into Models of Bureaucratic Policymaking," working paper.

Dranove, David, and David Meltzer. 1994. "Do Important Drugs Reach the Market Sooner?" 25 RAND Journal of Economics 402-23.

FERC. 1990. Hydroelectric Project Relicensing Handbook. Office of Hydropower Licensing.

Gilligan, Thomas W., William J. Marshall, and Barry R. Weingast. 1989. "Regulation and Theory of Legislative Choice: The Interstate Commerce Act of 1887." 32 Journal of Law and Economics 35-61.

Helland, Eric. 1999. "The Waiver Pork Barrel: Committee Membership and the Approval Time of Medicaid Waivers," 17 Contemporary Economic Policy 401-11.

Hird, John A. 1990. "Superfund Expenditures and Cleanup Priorities: Distributive Politics or the Public Interest?" 9 Journal of Policy Analysis and Management 455-83.

Joskow, Paul. 1974. "Inflation and Environmental Concern: Structural Change in the Process of Public Utility Price Regulation," 17 Journal of Law and Economics 291-327.

Magat, Wesley A., Alan J. Krupnick, and Winston Harrington. 1986. Rules in the Making: A Statistical Analysis of Regulatory Agency Behavior. Washington, D.C.: Resources for the Future .

Mayhew, D. 1974. Congress: The Electoral Connection. New Haven, Conn.: Yale University Press.

McCubbins, Matthew D., Roger G. Noll, and Barry R. Weingast. 1987. "Administrative Procedures as Instruments of Political Control," 3 Journal of Law, Economics, and Organization 243-77.

Mixon, Franklin G., Jr. 1994. "What Can Regulators Regulate? The Case of the Urban Heat Island Phenomenon," 53 American Journal of Economics and Sociology 403-14.

Moore, Michael R., Elizabeth B. Maclin, and David W. Kershner. 2001. "Testing Theories of Agency Behavior: Evidence From Hydropower Project Relicensing Decisions of the Federal Energy Regulatory Commission," 77 Land Economics 423-42.

Noll, Roger. 1974. "Government Regulatory Behavior: A Multidisciplinary Survey and Synthesis," working paper \#62, California Institute of Technology.

Olson, Mary K. 1995. "Regulatory Agency Discretion Among Competing Industries: Inside the FDA." 11 Journal of Law, Economics, and Organization 378-405.

1997. "Firm Characteristics and the Speed of FDA Approval," 6 Journal of Economics and Management Strategy 377-401.

- 2000. "Regulatory Reform and Bureaucratic Responsiveness to Firms: The Impact of User Fees in the FDA." 9 Journal of Economics and Management Strategy 363-95.

Peltzman, Sam. 1976. "Toward a More General Theory of Regulation," 19 Journal of Law and Economics 211-40.

Sigman, H. 2001. "The Pace of Progress at Superfund Sites: Policy Goals and Interest Group Influence," 44 Journal of Law Economics 315-44.

Stigler, George J. 1971. "The Theory of Economic Regulation." 2 Bell Journal of Economics and Management Science 3-21.

Upadhyaya, Kamal P., and Franklin G. Mixon Jr. 1995. "Regulatory Capture and the Price of Electricity: Evidence from Time Series Estimates." 22 International Journal of Social Economic 16-23.

Weingast, Barry R., and Mark J. Moran. 1983. "Bureaucratic Discretion or Congressional Control? Regulatory Policymaking by the Federal Trade Commission." 91 Journal of Political Economy 765-800.

Yaffee, Steven Lewis. 1982. Prohibitive Policy: Implementing the Federal Endangered Species Act. Cambridge, Mass.: MIT Press. 